\title{
New service development in e-government: identifying critical success factors
}

\author{
Spyros Angelopoulos \\ Information Systems and Management Group, Warwick Business School, \\ The University of Warwick, Coventry, UK \\ Fotis Kitsios \\ Department of Technology Management, University of Macedonia, \\ Naousa, Greece, and \\ Thanos Papadopoulos \\ Knowledge and Information Systems Management Group, \\ School of Management, University of Southampton, Southampton, UK
}

\section{New service development in \\ e-government}

Received 4 September 2009 Revised 8 November 2009,

6 December 2009

Accepted 7 December 2009

\begin{abstract}
Purpose - The purpose of this paper is to suggest a model that incorporates critical factors contributing to the success in new service development (NSD) projects in electronic government (e-government).

Design/methodology/approach - After a brief introduction to e-government and NSD in respect to models for successful implementation, the authors justify and build on the existing literature that advocates the use of critical success factors (CSFs) to study the implementation of these projects. They suggest a model that incorporates the determinants of success or failure for a new service through a set of variables.

Findings - This paper proposes a framework, which is believed to help with the empirical research of CSF in NSD. The suggested framework attempts to bring experience in leadership and coordination of work theory and practice together by synthesising the existing literature with real-life experience.

Research limitations/implications - The paper contributes to the e-government implementation literature in terms of suggesting a model that takes under consideration important CSF for implementing NSD.

Practical implications - The projects a number of implications for public sector scholars as well as administrators. A vast amount of taxpayer money can be saved if decision makers can promptly identify potential waste of funds in prone-to-failure projects.

Originality/value - The research aims at providing a better understanding of the underlying factors and dimensions that describe NSD in e-government through the suggestion of a model that takes under consideration important CSF for implementing NSD. Therefore, it expands the scope of NSD research in e-government context, stating the need for more research to be conducted regarding the NSD in e-government using CSF. By identifying the potential success or failure of future projects a number of implications for public sector scholars as well as administrators comes to light.
\end{abstract}

Keywords Government, Communication technologies, Services, Critical success factors, Public sector organizations

Paper type Research paper

\section{Introduction}

Electronic government (e-government) suggests the use of information technology (IT) and systems to provide efficient and quality governmental services to citizens, employees,

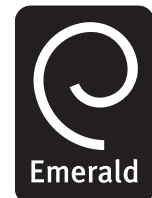

Transforming Government: People, Process and Policy Vol. 4 No. 1, 2010 pp. $95-118$

(C) Emerald Group Publishing Limited 1750-6166 
TG

4,1

96 businesses and agencies. Moreover, it increases the convenience and accessibility of government services and information to citizens (Carter and Belanger, 2005). The multiplicity of anticipated benefits that may stem from the implementation of e-government has led governments to invest heavily in technologies and systems.

The aim of the governments to provide not only improved and computerised but also innovative services in e-government has spanned services innovation literature in the public sector and boosted the study of new service development (NSD). However, a major portion of the literature on NSD has concentrated on the financial-service sector and hospitality industry (Kitsios et al., 2009), and there has been relatively no significant research on NSD in e-government and public sector. Moreover, e-government, sometimes perceived as buzzword in public administration (Yildiz, 2007), implies different things to different stakeholder groups (Grant and Chau, 2005; Halchin, 2004). Despite its numerous benefits - such as greater public access to information and a more efficient, cost-effective government - e-government is contingent upon the willingness of the citizens to adapt it.

Although implementing NSD remains a challenge for researchers and practitioners alike, there has been relatively little research exploring the implementation of NSD in e-government. To address this gap and under the critical success factors (CSFs) prism (Shah and Siddiqui, 2006), this paper contributes to the development of new services in e-government literature by suggesting a model that considers CSF for the implementation of e-government projects. The main argument developed in this paper is that the implementation of NSD in e-government is multi-faceted, and since the benefits of e-government are much anticipated by governments but the financial investments involve high risk, it is necessary to suggest a model based both on previous literature in the field and research, which will take under consideration the majority of the factors that secure the successful outcome of future investments and implementations of NSD in e-government.

To explore further the arguments set out above, this paper is divided as follows: after a brief introduction to e-government (Section 2), challenges for NSD are discussed (Sections 2 and 3) and the need for an approach based on CSF is presented (Section 4). Sections 5 and 6 then suggest a conceptual framework based on the CSF approach and the recommended methods for investigating the factors of the model, whereas the final Section 7 concludes the paper.

\section{A brief introduction to e-government}

E-government aims at providing new or improved, more accessible and responsive government services, adapted to the needs and expectations of citizens. Despite its relatively short history (Dwivedi, 2009) research on e-government has been strongly characterised by a multi-disciplinary nature (Irani and Dwivedi, 2008). It comprises the use of information and communication technologies (ICT) in order to deliver public services to citizens and businesses, and entails the transformation of public services available to citizens using new organizational processes as well as new technological trends (Gunter, 2006). E-government is regarded as a player with a significant role in enabling greater citizen involvement in civic and democratic matters in the sense of direct democracy as the one practiced in the city-states of ancient Greece.

E-government is designed to facilitate a more integrated mode of governance. It encapsulates the relationships between governments, their citizens as well as their suppliers by the use of electronic means (Means and Schneider, 2000). The United Nations 
and the American Society for Public Administration (ASPA) (2002) defines e-government as the utilization of the world wide web for the delivery of government information as well as services to citizens. Jaeger (2003) believes that it may also include the use of other ICT in addition to the internet, such as database, networking, discussion support, multimedia, automation, tracking and tracing and personal identification technologies.

In studying the characteristics of e-government, Doty and Erdelez (2002) suggest that e-government should enable an open government with transparency as well as responsiveness. Hence, e-government means utilizing technology to enhance access efficient delivery of government information and services (Brown and Brudney, 2001). Heeks (2003) and the World Bank (2004) assert this view by proposing that the use of technology is fundamental to improve the activities of public sector organizations. According to the Center for Democracy and Technology (CDT) (2002) e-government is the use of ICTs in order to transform government by making it more accessible, effective and accountable. However, e-government is not about the use of technology or technological innovation per se; it is the interplay between technology, policy and various stakeholders, which come together to construct and offer new or improved services to citizens. Technologies by themselves do not fundamentally define what e-government is and what it will be (Yildiz, 2007).

Last but not least, Hackney et al. (2005) suggest that e-government constitutes a burgeoning phenomenon with huge investments being made to modernise public sector institutions at all levels. Such dramatic change is problematic in any organization, and the political, managerial and cultural environments set within government present an additional challenge. This complexity is historically founded and consistently embedded through a structure of co-operation between executive officers, elected legislative members and citizens, who form the foundations of the democratic process.

\section{The implementation of e-government: challenges for NSD}

Fundamental changes have occurred in the structure of most countries' economies, with services becoming the major sector of economic activity (OECD, 2000a, b) and therefore, meeting the challenges of such an unstable environment is not easy. Governments all around the world have been involved in various massive projects with the objective of getting as many public services electronically enabled as possible during the first decade of the twenty-first century. In this attempt, the political leadership (CDT, 2002), as well as several economical factors are of great importance. This can be attributed partly to the fact that online technologies are envisaged as playing a significant part in the re-engagement of politically alienated electorates in civic processes. The utilization of ICTs in the government section and administration does not constitute a panacea; however, their use can be perceived as a means to manage the limitations of bounded-rationality and provide the underlying infrastructure for improved decision making (Simon, 1976).

Research in the past has investigated issues in respect to the implementation of e-government using diffusion models. For instance, by using Roger's (1995) Diffusion Theory, studies have focused on the adoption of IT in the public sector (Brudney and Selden, 1995; Bugler and Bretschneider, 1993; Brudney and Selden, 1995; Norris and Demeter, 1999; Norris and Campillo, 2000; Moon, 2002; Moon and Norris, 2005; Elliman et al., 2005), suggesting that, inter alia, the size of administration and professionalism are the primary determinants of the adoption of computer technology. Rogers (1995) presents five categories of determining variables for the rate of adoption: perceived attributes of the innovation, type

\section{New service development in \\ e-government}


TG

4,1

98

of innovation decision, communication channels, nature of the social system and extent of the change agent's promotion efforts. Berry and Berry (1999) suggest two categories of innovation and diffusion models, namely diffusion models and internal determinants models. In their study they present four diffusion models, that is, the national interaction model (learning model), the regional diffusion model, leader-laggard models and vertical influence models. In internal determinants models, they aim to incorporate internal factors (motivation, size, resources, etc.). In another study, Choudrie and Lee (2004) found that the use of broadband within government departments and agencies improved the quality of public services, and encouraged previously bureaucratic organizations to re-engineer the way services are delivered to citizens. However, as Moon and Norris (2005) suggested, no single diffusion model best explains all cases (Moon and Norris, 2005).

The information systems (IS) success model (DeLone and McLean, 1992) and the technology acceptance model (TAM) (Davis, 1989; Figure 1) suggests another means to study the implementation of e-government by measuring perceived usefulness and perceived ease of use influence one's attitude towards system usage, which influences one's behavioural intention to use a system, which, in turn, determines actual system usage. The success factors presented in Davis' model have to do mainly with the acceptance of organizational software, but have been tested for various users and types of systems (Venkatesh and Davis, 2000; Venkatesh and Morris, 2000) and user adoption of e-commerce (Gefen and Straub, 2000; Moon and Kim, 2001; Gefen et al., 2003; Gefen and Pavlou, 2002). However, TAM constructs represent the subjective user assessments of a system and may not be representative of its objective acceptance (Carter and Belanger, 2005).

Despite the emergence of frameworks, which predict and study the success of IS and, in our case, e-government, barriers do exist. These may concern, for instance, the high cost or the low security of the needed infrastructure can impede its implementation and adoption. The integration of various IT applications and components inside and outside the organizational boundary remains costly and time-consuming due to the heterogeneity of the computing environments involved in public sector organizations (Themistocleous and Irani, 2002). Literature (Bonham et al., 2001; Bourn, 2002; Dillon and Pelgrin, 2002; McClure, 2000; National Research Council, 2002) agrees that governments face a shortage of technical infrastructure. This shortage presents a significant barrier in the development of the capabilities of government organizations to provide online services and transactions. They also agree that unreliable IT infrastructure in public sector organizations will certainly degrade the e-government performance.

A frequently cited barrier in literature seems to be the need for security and privacy in an e-government strategy (Daniels, 2002; James, 2000; Joshi and Ghafoor, 2001; Lambrinoudakis et al., 2003; Layne and Lee, 2001; Bonham et al., 2001; Gefen and

Figure 1.

Technology acceptance model

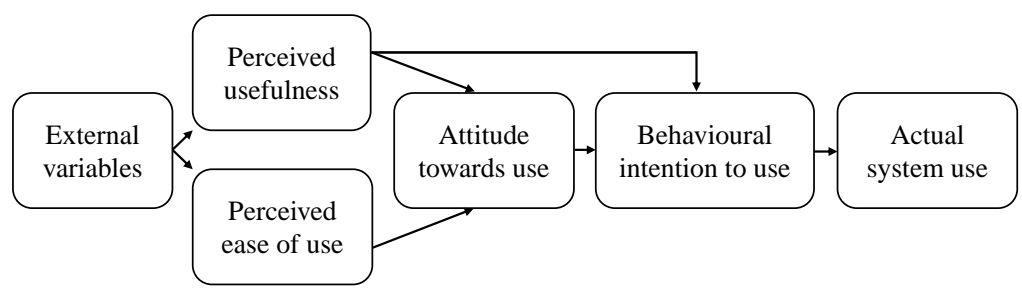

Source: Davis (1989) 
Pavlou, 2002). The shortage of IT skills is also a barrier, which contends many challenges regarding the efficiency of a public administration to provide innovative e-government services (Chen and Gant, 2001; Heeks, 2001; Ho, 2002; Moon, 2002). Finally, a major barrier to the adoption and implementation of e-government is funding (Bonham et al., 2001; Heeks, 2001; Ho, 2002), which also relates to the business procedure of government, management strategy and organizational culture (Lenk and Traunmuller, 2000; McClure, 2000).

Organizational barriers relate to structural issues such as fragmentation, poor relations and communication between the functional departments, and an acceptance of the strategic benefits of new initiatives by the senior management (Aichholzer and Schmutzer, 2000; Fletcher and Wright, 1995; Northrop et al., 1994; Nedovic-Budic and Godschalk, 1996). Moon (2002) concludes that, in order to enhance the effectiveness of e-government practices, public sector organizations would need to progress towards a higher level of e-government development, which will require a greater number of highly trained technical staff.

Finally, in their study of extant literature on e-government policy formulation, implementation and execution, Altameem et al. (2006) suggest a plethora of factors leading to success and failure of e-government and to elaborate on the underlying enabling and inhibiting conditions. They present a multi-factor model that aims to take under consideration governing factors, that is, the factors which influence people's decisions to adopt e-government initiatives and furthermore can assist or limit the public sector's effort to diffuse e-government initiatives; technical - the infrastructure, tools and applications required to enable government agencies to participate in the adoption of e-government and organizational, such as policy and legal issues, quality of service, training, organizational structure and culture.

Although e-government has been seen as an agent for change (Sarikas and Weerakkody, 2007), the transformation from its implementation on the front-office needs to be expanded to the back-office and this is referred in the literature as t-government. T-government is defined as a radical change in the way governments conduct their business internally and externally (Murphy, 2005); is the highest level of maturity for e-government projects and therefore it is the most challenging to implement (Layne and Lee, 2001) being as such a highly complex and challenging endeavour (Earl, 1994; West, 2004; Scholl, 2002). Reference to this final stage of e-government has extensively appeared on the relevant literature (Layne and Lee, 2001; Baum and Maio, 2000; Murphy, 2005; Balutis, 2001; Irani et al., 2006; Weerakkody and Dhillon, 2008) and its objective is the re-engineering of governmental processes by leveraging the benefits from IT investment (Janssen and Shu, 2008; Smith, 2007) to serve citizens more efficiently and effectively (Palanisamy, 2004).

Three perspectives part this new concept of t-government named under citizen centricity, shared service culture, as well as professionalism (Irani et al., 2007) and despite the fact that they rely on the legacy of e-government, they are the ones that e-government itself lacked in the past. A list of the critical factors that distinguish e-government from t-government is presented in Table I.

This socio-cultural transformation that emerges from the desired inclusion (Leitner, 2003), has led to a more modern way of governance. Up until now, although there is an increasing interest for the its development (Pagani and Pasinetti, 2009) primarily the government of the UK - while laying on the third stage of development (Murphy, 2005) - is focused on t-government as a model for the delivery of e-services and the outcomes from

\section{New service development in \\ e-government}

99 


\section{TG \\ 4,1}

100

$\underline{100+20}$

Table I.

Differentiation between e-government and t-government
E-government

Putting government services online

Focus

Citizens involvement

Business involvement

Service delivery

Evaluation

Resource management

Integration

Business model

IT role

Access and accessibility

Online transacting

Push-model

Stage model growth

Resource allocation

Shared service platform

Technological capability

Enabling online delivery
T-government

Making the government

transformational through IT

Build social capital

Supply chain integration

Pull-model

Benefit realization

Professionalism

Shared service culture

Strategic governance

Enabling the transformation of the business of government

Source: Irani et al. (2007)

this new phenomenon are not yet discernible and no set of best practices has yet been developed (Irani et al., 2007). One of the main goals of this strategy is the use of IT for the improvement of communications within and between public organizations but its implementation presents a series of risks, since data sharing is its key enabler (Combe, 2009).

Despite the existing literature on the implementation of e-government, there is a need for further research to be conducted. Literature has not shed enough light on the development of new services in e-government yet. Various initiatives investigate the application of quality management principles to the delivery of electronic public services (Halaris et al., 2007), but manifold problems related to quality of public e-services still exist (E-government Unit, 2004). The noticeable shift in the provision of governmental services from traditional channels to web-based ones has been obscured by limitations due to the poor quality of services (Papadomichelaki et al., 2006). In the past few years, very few academic studies have concentrated on this area, which implies that the knowledge of NSD in e-government has not advanced very far. The major portion of research on the development of new services has concentrated on the financial-service sector and some recent attempts have examined the hospitality industry, but so far, there has been relatively little research on NSD in the public sector. This study addresses exactly this gap: it aims to study the relationship between NSD and e-government. But before embarking on a discussion of addressing the gap, the following section gives an overview of NSD.

\section{New service development}

One of the major stumbling blocks in the context of service development is the inability to describe the service process characteristics, that is, to depict them so that employees, citizens as well as public sector administrators alike know what the service and what their role in its delivery is, as well as understand all of the steps and flow involved in the service process (Zeithaml and Bitner, 1996).

This fact has brought the high failure rate of new service projects. The success rate of new service projects is an average 58 per cent (Griffin, 1997). In other words, four out of ten new service projects fail in the market. Heeks (2003) empowers this belief with a recent survey regarding the success and failure rates of e-government initiatives in developing and transitional countries, where he identified that 35 per cent of projects are total failures (e.g. the failure of decision support systems in East Africa); further, half can be considered 
to be partial failures (e.g. the partial failure of management IS in Eastern Europe); and roughly 15 per cent of e-government services can be characterized as successful. During the same year, the World Bank (2003) reported that its sector-based projects with ICT components faced an alarmingly high failure rate, with 50 per cent suffering disputes and 80 per cent requiring contract amendments.

Although many studies (Layne and Lee, 2001; Holden et al., 2003; Lee et al., 2005; Sarikas and Weerakkody, 2007) identify that most e-government initiatives tend to stagnate at the transaction stage of development, very few succeeded in providing added value, sophisticated, truly efficient as well as transparent one-stop e-services (Weerakkody et al., 2007). Most of these failures have been attributed to the inability of governments around the globe to encapsulate business process (BP) and IS re-engineering in response to the respective e-government model. These failures have resulted in an even more pressing need to integrate the front-office and back-office systems and processes (West, 2004; Sarikas and Weerakkody, 2007) and changes to BP in order to fully encompass the potential of e-government initiatives (Kim et al., 2007).

A plausible approach is the use of different mapping techniques where an existing service is described visually to find potential weak points or to evaluate alternative procedures (Shostack, 1984; Ekholm and Wrange, 1996; Wrange, 1997). Literature suggests at least five different kinds of mapping techniques: service blueprinting (Shostack, 1981), service mapping (Kingman-Brundage, 1989), the structured analysis and design technique (Congram and Epelman, 1994), multilevel mapping (Norling, 1993) as well as service process rationalization method (Kim and Kim, 2001).

Shostack (1985) was one of the first researchers, who looked at service development. Her molecular model has already become a classic as it separates between intangible and physical parts of the service and she also identifies bonds, which later became an interesting object of versatile research. Scheuing and Johnson (1989), proposed a 15-stage model for NSD in which they paid special attention to test the service-to-become from the concept, service, process and marketing point of view (Kokko, 2005). Wilhelmsson and Edvardsson (1994) presented a four-stage development model, where the stages are: idea phase, project stage, development phase and implementation phase. According to the researchers the phases overlap and sometimes one has to return to an earlier phase. Edvardsson (1996a, b) model for service development consisted of three essential parts: development of the service concept, development of the service process and development of the service system. These components have different kinds of interrelationships depending on the character of the service development project. de Brentani (1993) studied 106 new industrial services from 37 financial institutions. Approximately, half of the services were considered by companies themselves to be successful. She came up with four significant factors that are positively linked to new service success. The four factors were: supportive, high involvement NSD environment, formal and extensive launch programme, formal upfront design and evaluation and expert-driven NSD process. In her study she found two factors, which were not significant to new service success: marketing-dominated and customer-driven NSD process.

Martin and Horne (1995) also shed light at the CSF methodology. In their study of 88 firms concerning a total of 176 service innovations, they found that in five out of six factors, there were significant differences between the most and least successful service innovations. The significant differences were found in the following factors: direct overall customer participation in service innovations, direct participation of senior 
TG

4,1

102

management in service innovations, direct participation of customer contact personnel in service innovations, direct participation of non-contact personnel in service innovations and the greater use of customer information. The only non-significant factor was the participation of other outside resources (Martin and Horne, 1995).

Edvardsson (1995) made a general synthesis of characteristics of the service development processes. He presented nine points and he further gives a list of eight potential factors for successful NSD, which give quite a complex picture of the NSD as a process. Additionally, Tax and Stuart (1997) presented a normative seven-step planning cycle through which they try to integrate the potential new service successfully with the existing service system. Starting with an audit of the original service system in the firm, the requirements of the market and the extent of change that the new service represents were analysed and the effects that the new service will have on the existing service system were assessed. Grönroos (1990) presented a dynamic six-stages model for developing the offering of the service. This approach considered both customer features and organizational features. Finally, Fitzsimmons and Fitzsimmons (2000) called for a totally new paradigm for service development: real-time marketing. In their vocabulary real-time marketing practically means that an offering is under modification during the contact between the contact person and the customer. The authors suggested that real-time marketing will become the dominant marketing paradigm. Further, they saw this paradigm shift as one way of blurring the traditional definitions separating products and services from each other and, at the same time, increasing the sensitivity towards customer values and needs for customization (Kokko, 2005).

Having briefly reviewed the literature regarding e-government and NSD, the question still remains: what is the relationship between e-government and NSD and how can factors influencing their success be traced? This is done through the suggestion of a framework and a methodology based on CSF, discussed in the following sections.

\section{Success and failure methodology: justifying the need for a CSFs approach}

New development is a key factor for a significant corporate performance, and investigation regarding success factors in innovation process has been carried out for both products and services. For manufactured tangible goods, a large number of studies since 1970 have established a wealth of evidence about what factors affect new product outcomes. Similarly, researchers have explored new service success and failure to achieve high levels of performance. Despite this extensive documentation on how to achieve success, new product development remains a high-risk venture (de Brentani, 2001).

The approaches for the aforementioned studies have ranged in matter of methodology from direct matched pairs to multivariate analysis techniques such as factor, regression or discriminant analysis. They have also varied from single case studies to multi-industry approaches; and from examining a series of successful cases to examining the converse, a number of failed new products. Other studies have examined both successful and unsuccessful (a comparative analysis) cases simultaneously (Edgett and Parkinson, 1994).

Both Cooper and Marquis have examined success and failure in isolation from each other in their earlier work (Myers and Marquis, 1969; Cooper, 1979a, b). In later works both researchers have adopted a success - failure methodology for analysing new products thus establishing control groups (Maidique and Zirger, 1984; Cooper and Kleinschmidt, 1987a, b, c). No discrimination can be made between success and failure 
without the use of a control group. Instead, a researcher is limited to describing traits that were common to one group or the other, and is unable to explicate why the product or service became either a success or a failure (Edgett and Parkinson, 1994). The process of comparing a number of successful and unsuccessful new products/services simultaneously with one set of criteria enables the researcher to establish two dependent variables - success and failure. This technique differentiates between successful new product practices from those that fail (Maidique and Zirger, 1984).

Innovative product screening models have been developed by comparing successful and failed new products (de Brentani, 1986). The need to develop products differently, depending on the type of product, has been examined successfully via a comparative study of US and UK manufacturing firms (Johne and Snelson, 1988, 1989). The approach has also been successfully applied as Parkinson (1981) used it for comparing new product development in British and German machine tool manufacturers, as a discriminating function in a number of studies on new product success and failure.

The comparison method has also been used with good results in a number of studies on new services. For example, Edgett and Parkinson (1994) used it for comparing NSD in British building societies that were registered and maintained active membership status in the Building Societies Association; Edgett (1994) used it for comparing NSD activities in British banks and building societies (building societies are similar to US savings and loans). In a study of new commercial service companies Cooper and de Brentani (1991) compared successful and unsuccessful services in a way similar to the methodology previously used by Cooper (Edgett and Parkinson, 1994; Ernst, 2002).

The empirical studies, which have investigated the success factors at the project level, indicated that success or failure is not the result of managing one or two activities very well; rather it is the result of a holistic approach, managing several aspects competently and in a balanced manner (Johne and Storey, 1998). The methodological approaches for these studies have varied in identifying the CSFs from direct matched pairs to multivariate analysis techniques such as factor, regression and discriminant analysis. They have also varied from single case studies to multi-industry approaches; and from examining a series of successful cases to examining the converse, a number of situations where the new product failed. Another, more encompassing series of studies has used the methodological approach of examining both the successful and unsuccessful (a comparative analysis) cases simultaneously (Edgett and Parkinson, 1994).

Although a vast variety of methodologies could be used, the CSFs approach is a well-established technique in the IS field and fits better with this research (Ang and Teo, 1997; Butler and Fitzgerald, 1999; Han and Noh, 2000; Holland et al., 1999). The process of comparing a number of successful and unsuccessful new products simultaneously with one set of criteria enables the researcher to establish two dependent variables - success and failure. The success of the comparative methodology for new services indicates that this approach is suitable and reliable for the study of new services development in the implementation of inter- and intra-organizational new services development in e-government. The success of the comparative methodology for tangible new products and new services indicated the usefulness of the approach for this study. Based on the CSF approach, a conceptual framework for the implementation of e-government is suggested in the following section.

\section{New service development in \\ e-government}

103 
TG

4,1

104

\section{Suggesting a CSF-based conceptual framework}

Conceptual frameworks can be built in many different ways. On a general level the framework should assist us in our orientation towards different component is associated with the studied phenomena (Engelbart, 1962). Furthermore, it should establish some kind of shared vision of the target area of interest. In this study, the conceptual framework has been given the role of creating order and showing different aspects having an impact on the service development process. Moreover, it will investigate the anticipated relationship between the process development and the potential successful or failure result. The approach has been chosen because the author feels that it explicitly supports the empirical part of this study and very generally takes into consideration the reviewed theories. As the entire study is strongly management-orientated, the conceptual framework has been also seen from a management point of view.

Previous researchers have argued that it is necessary for further empirical studies in this subject area to explore a specific service industry rather than to take the traditional cross-sectional approach (Cowell, 1988, Easingwood, 1986). Therefore, only a single service economy sector comprised the resulting sample frame. The definition of the sample is very important in order to ensure the validity of data collecting and the representative of the population. The target of the research is the largest sample according to the studies with related content, which have been carried out in the past. These are all the relevant studies that have been executed in the field of new product and service development up-to-date. Their sample-size has been taken into consideration for the needed size of the sample selection of this research and can be summarised in Table II (Kitsios et al., 2009). The following table does not attempt to lend itself to the creation of taxonomy; rather its main objective is to provide the necessary thresholds of the needed sample size for the application the framework suggested by this study.

To avoid bias, the proper needed sample for the research to be valid has been determined to conclude at least 60 governmental agencies with at least 120 e-government projects; one of success and one that has already been characterized as failure. The governmental organizations will be selected from a pool of agencies that have already implemented the second stage of e-government development, according to Layne and Lee (2001), depending on the services they have already been provided online to citizens for at least three years. Finally, a random-number-generator will be used for the unbiased selection of the agencies from the pool.

Figure 2 shows the conceptual framework for offering development suggested by this study. The framework has been built on the basis of the existing literature. The attempt of the authors has been to create a framework, which fulfils three criteria: first, it covers the most important topics, which in the literature have been stressed in connection with offering development. Second, it should be flexible enough to allow for new insights. Third, it takes into account both operative and strategic issues. All parts of the framework have repeatedly been mentioned in the reviewed literature.

The proposed conceptual framework examines the relations between the behaviour of the organization for the service innovation, the idea generation sources, the actions for the development, the organizational structure impact, the resources allocation impact within the organization as well as the impact within the relevant marketplace in order to identify factors that express the phenomenon of NSD. Eventually, by identifying the CSF, we will be able to predict the potential success or failure of 


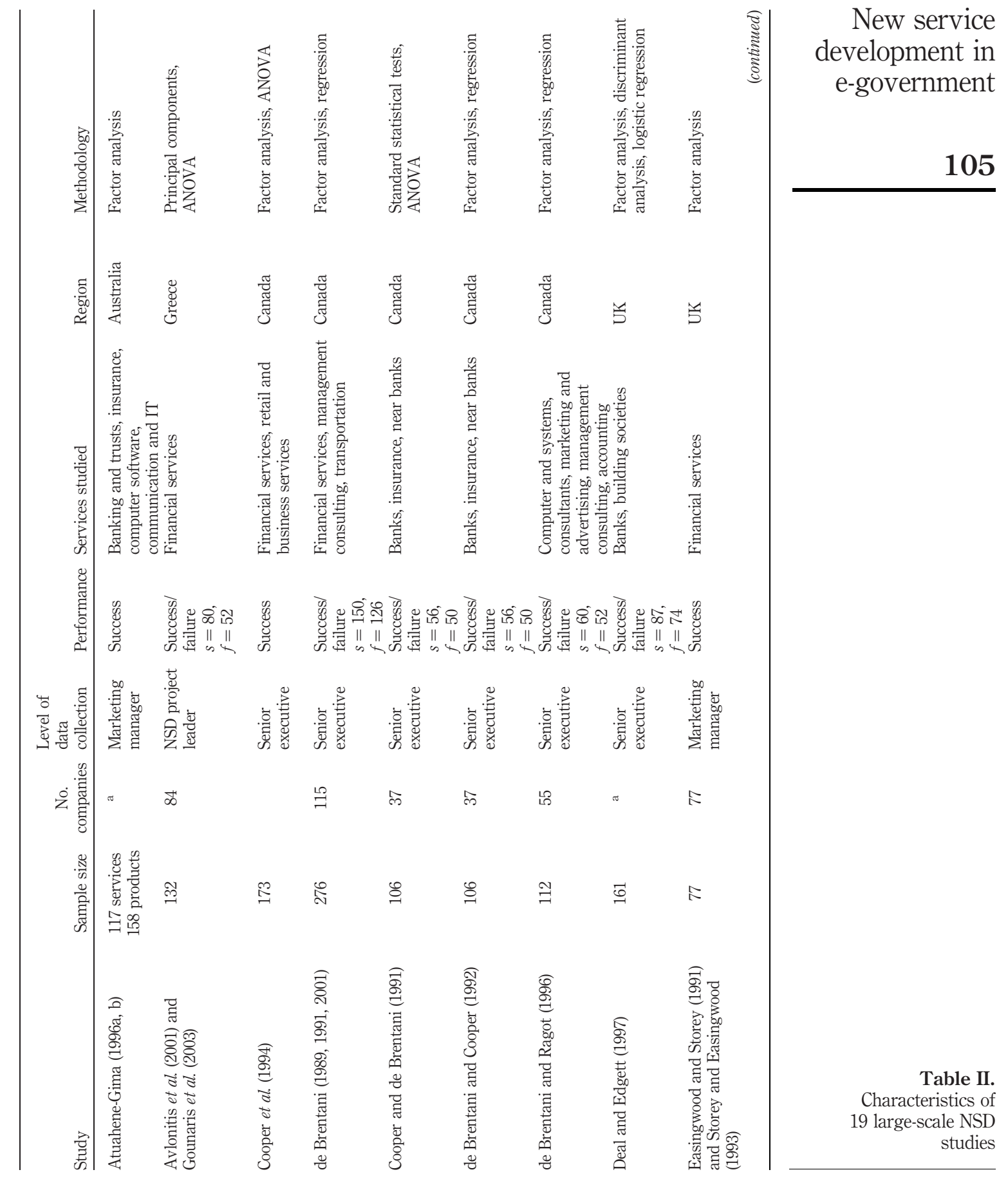




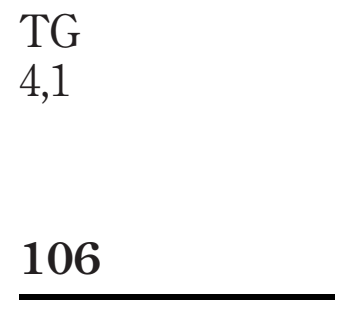

Table II.

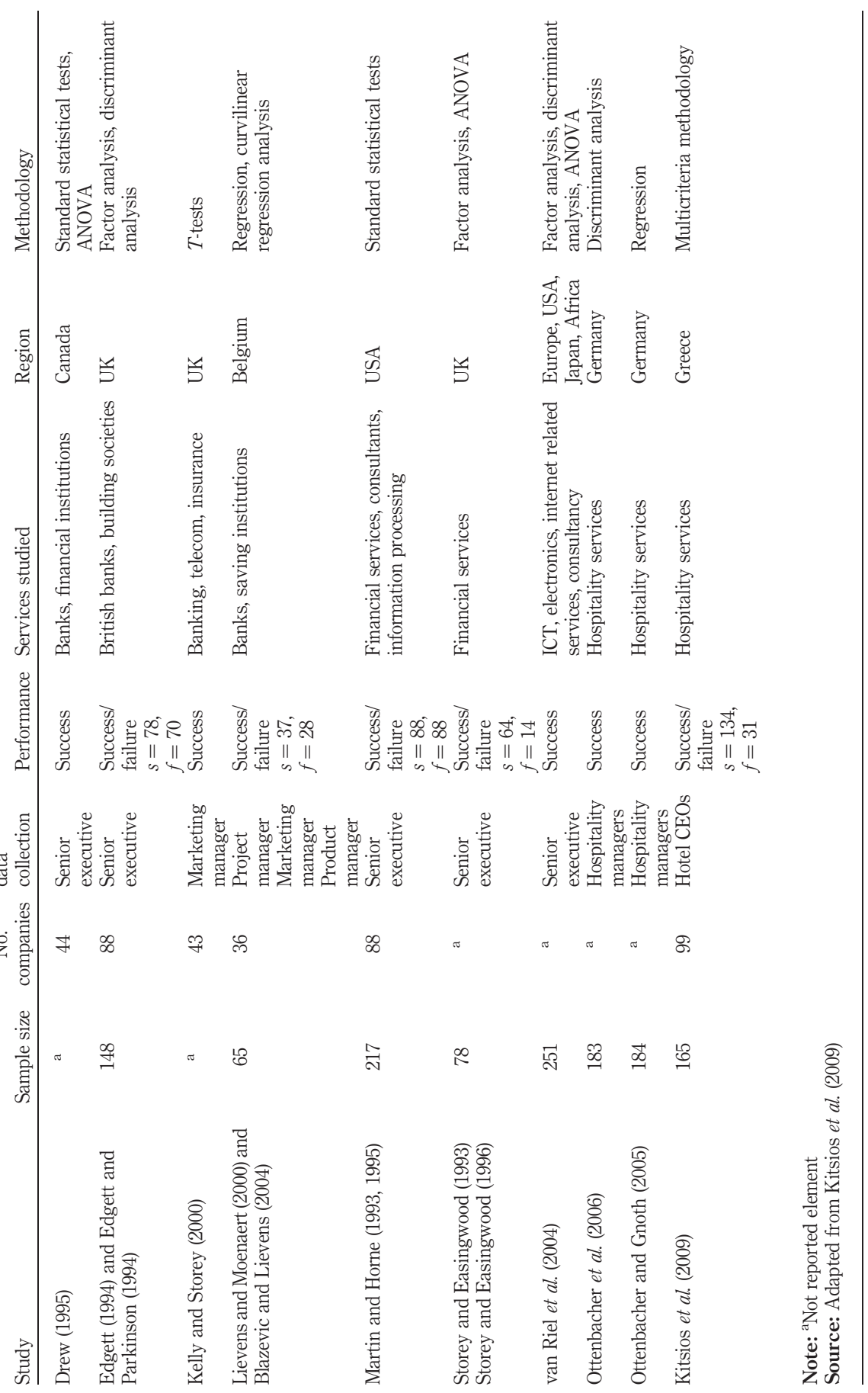




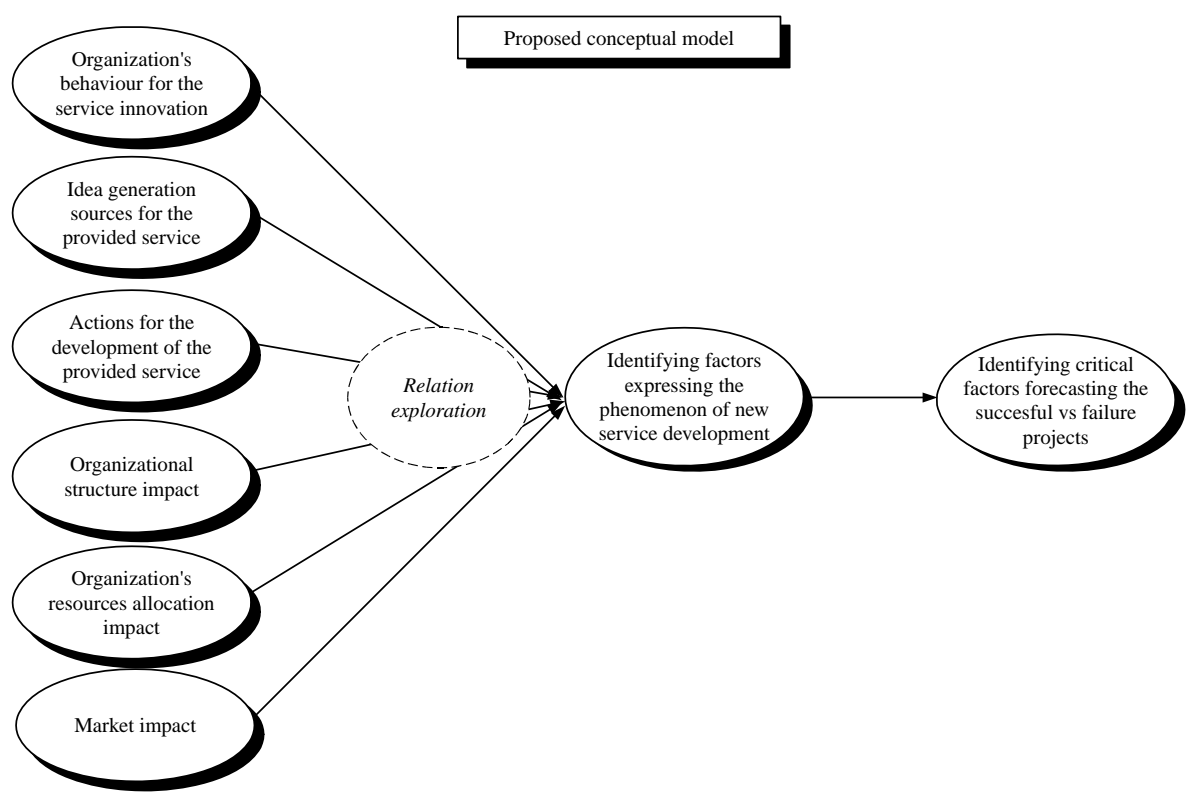

\section{New service development in e-government}

future projects. The authors feel that the chosen simple and visual way of presenting the framework serves best the study as a whole.

\section{Proposed survey design and data analysis strategies}

The suggested framework attempts to bring experience in leadership and coordination of work theory and practice together by synthesising the existing literature with reallife experience. The main goal of this study is to achieve a better understanding of how successful new e-government services are developed. This will be accomplished by examining the actual development activities and some of the accompanying organizational matters. The successful application of a comparative methodology with a series of multivariate tests, will achieve the isolation of a number of potential factors that affect the outcome of a new service and eventually lead to the organizational factors, which are critical to the success in e-government adoption.

A number of variables will be generated around the concept of NSD based on the previous literature and the results of a number of in depth personal interviews conducted with executive managers and officers from the public sector. Subsequently, five experts experienced in innovation management, NSD, data analysis and forecasting, public sector administration as well as scale development, will review the questionnaire. A pre-test will be then administered as a safety valve, modelling as closely as possible the final methodology for the principal survey. All seven phases of the questionnaire construction method, which are preliminary analysis of service development, market environment analysis and interview network planning, testing questionnaire construction, pilot questionnaire construction, questionnaire trial in real time, final questionnaire construction and interviews conducting, can be previewed in Figure 3. 
TG

4,1

108

To identify the determinants of success or failure for a new service, a set of variables will be developed and tested in categories. The study will examine the relations between the required dependent variable for the appropriate description of the NSD and the potential independent variables. The visual presentation of the aforementioned variables enhances this study as a whole (Figure 4).

First, respondents will be asked to select and refer to one successful project. Then, they will be asked to indicate the level of quality of performance with the way each one of the variables reflected the events that occurred during its development. This process will be repeated for a project that the respondent considered to have been a failure for the organization. Each respondent in terms of their own organization's interpretation of whether or not the service meets their success criteria will define success and failure. Each set of the variables will be measured using a five-point Likert-type point scale anchored at each end with "percentage of $0 \%$ - not done" (1) and " $100 \%$ - completely

Preliminary analysis of service development Bibliography research

New product development

New product development in the service sector

New product development in the public sector

Draft questionnaire shaping

Personal interviews - questionnaire filled out

(random sample -3 executives interviews)

Criteria identification in new service development

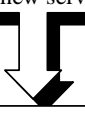

Market environment analysis and interview network planning

Figure 3.

Questionnaire construction method

Testing questionnaire construction

( 6 interviews 3 academic experts, 3 public administration executives)

According to market environment analysis

Process development requirements and data analysis techniques a questionnaire is shaped in order to be filled out by the appropriate sample of executives that will be defined later

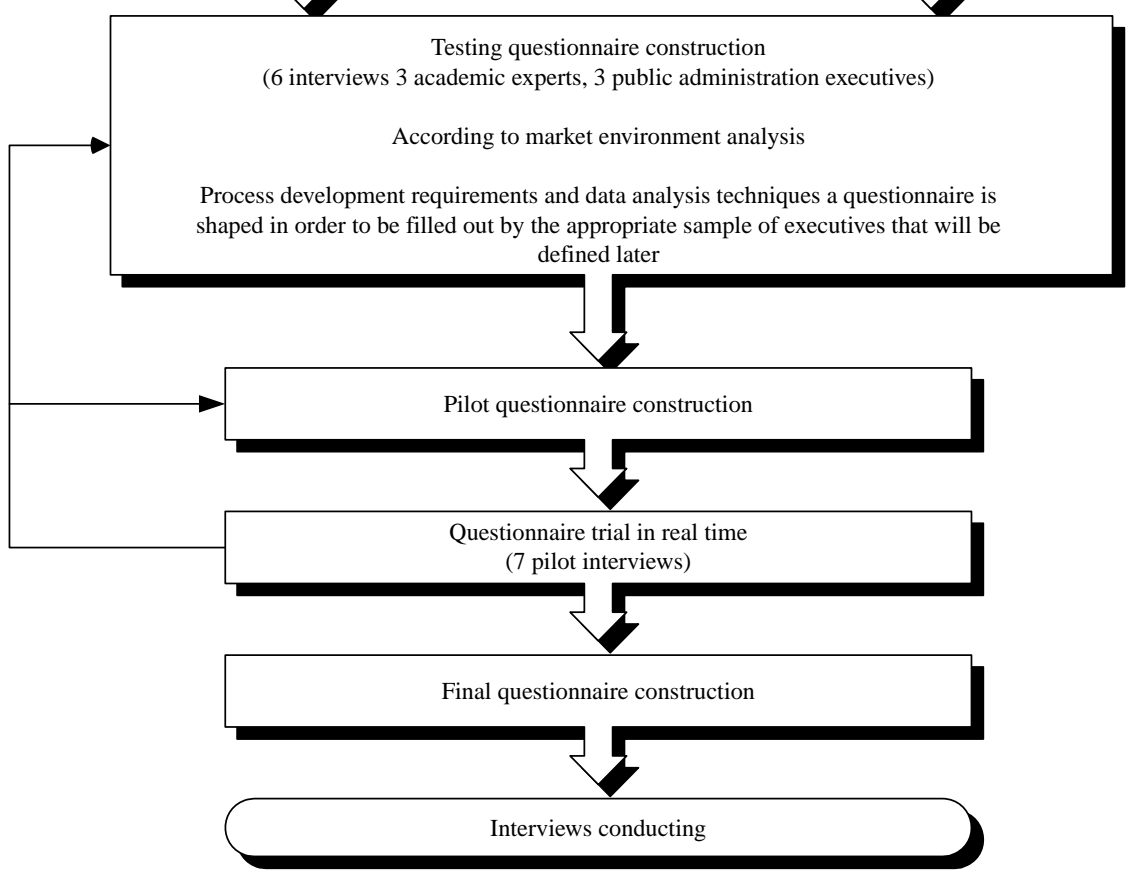

Source: Adapted from Kitsios (1996) 
done" (5). By this approach a more reliable rating is produced compared to continuous scales (Churchill, 1987). Data collection determined to be arranged first by a communication with the corresponding manager and second with an in depth interview on site if the communication proves positive for us. Interviews duration is estimated to be from 90 to 120 minutes.

Three major techniques for the multivariate data analysis will be employed: factor analysis to reduce the number of variables to a more manageable number; two-group discriminant analysis to develop a model for predicting either success or failure; logistic regression to verify the results of the sensitive discriminant analysis. However, before beginning this analysis the issue of scale reliability will be addressed first (Edgett and Parkinson, 1994; Zopounidis and Doumpos, 2002). Subsequently, the identification of a new predictive model will be conducted which could effectively predict success and failure.

A vast amount of money derived from tax-payers can be saved if decision makers can promptly identify potential waste of funds in projects that are most likely to end-up as failures.

\section{Conclusions}

In the last years few academic studies have concentrated on the implementation of NSD in e-government, and hence the knowledge of implementing NSD in the public sector has not advanced very far. This study proposed a framework to suggest a number of CSF for the development of new services in e-government. The specific model is based on both previous literature on NSD and e-government new factors and aims at providing a better understanding of NSD dimensions in ensuring the success of e-government. Aided by a future application of a comparative methodology with a series of multivariate tests, the model seeks to isolate of a number of potential factors that influence and secure the successful outcome of a new service. Therefore, through the introduction of the model and the factors, this study addresses the gap in the literature regarding the correlation between NSD and e-government and contributes to the development of successful new e-government services.

By identifying the potential success or failure of future e-government implementations, implications for both research and practice come to the fore. The paper contributes to the e-government implementation literature in terms of suggesting a model that takes under consideration important CSF for implementing NSD. Furthermore, there are implications by the use of the model for public sector practitioners, managers, and administrators. A vast amount of tax-payer money can be saved if decision makers can promptly identify

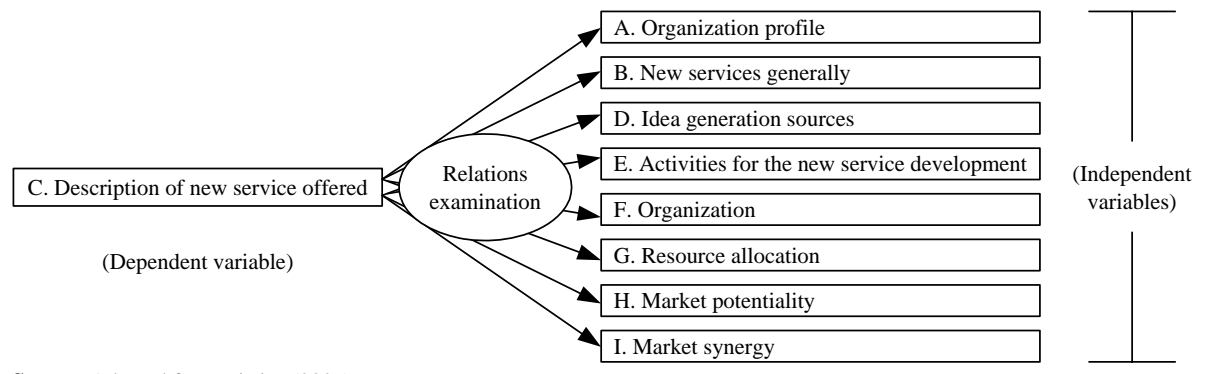

Source: Adapted from Kitsios (2006)
Figure 4. Process analysis 
TG

4,1

110

potential waste of funds in prone-to-failure projects. A limitation of the model lies in the fact that it has not been yet tested; however, eventually, the results of an exploratory study will be summarised in an improved conceptual model for further research.

\section{References}

Aichholzer, G. and Schmutzer, R. (2000), "Organisational challenges to the development of electronic government", paper presented at 11th International Workshop on Database and Expert Systems Applications, IEEE Computer Society, London.

Altameem, T., Zairi, M. and Alshawi, S. (2006), "Critical success factors of e-government: a proposed model for e-government implementation", IEEE, available at: http://ieeexplore.ieee.org/stamp/stamp.jsp?arnumber $=04085489$

Ang, J. and Teo, T.S.H. (1997), "CSFs and sources of assistance and expertise in strategic IS planning: a Singapore perspective”, European Journal of Information Systems, Vol. 6 No. 3, pp. 164-71.

Atuahene-Gima, K. (1996a), "Differential potency of factors affecting innovation performance in manufacturing and services firms in Australia", Journal of Product Innovation Management, Vol. 13, pp. 35-52.

Atuahene-Gima, K. (1996b), "Market orientation and innovation", Journal of Business Research, Vol. 35 No. 2, pp. 93-103.

Avlonitis, G.J., Papaststhopoulou, P. and Gounaris, S.P. (2001), “An empirically-based typology of product innovativeness for new financial services: success and failure scenarios", Journal of Product Innovation Management, Vol. 18 No. 5, pp. 324-42.

Balutis, A.P. (2001), "E-government 2001. Part I: understanding the challenge and evolving strategies", The Public Manager, pp. 33-7.

Baum, C. and Maio, A.D. (2000), Gartner's Four Phases of E-government Model, Gartner Group, Stamford, CT.

Berry, F.S. and Berry, W. (1999), "Innovation and diffusion models in policy research", in Sabatier, P. (Ed.), Theories of the Policy Process, Westview Press, Boulder, CO, pp. 169-200.

Blazevic, V. and Lievens, A. (2004), "Learning during the new financial service innovation process: antecedents and performance effects", Journal of Business Research, Vol. 57, pp. 374-91.

Bonham, G.M., Seifert, J.W. and Thorson, S.J. (2001), "Transformational potential of e-government: the role of political leadership", European Consortium for Political Research, which was held at the University of Kent, Canterbury.

Bourn, J. (2002), Better Public Services through E-government, The National Audit Office, London.

Brown, M.M. and Brudney, J.L. (2001), “Achieving advanced electronic government services: an examination of obstacles and implications from an international perspective", paper presented at the National Public Management Research Conference, Bloomington, IN.

Brudney, J. and Selden, S. (1995), “The adoption of innovation by smaller local governments: the case of computer technology", American Review of Public Administration, Vol. 25, pp. 71-86.

Bugler, D. and Bretschneider, S. (1993), “Technology push or program pull: interest in new information technologies within public organizations", in Bozeman, B. (Ed.), Public Management: The State of the Art, Jossey-Bass, San Francisco, CA, pp. 275-93.

Butler, T. and Fitzgerald, B. (1999), "Unpacking the systems development process: an empirical application of the CSF concept in a research context", Journal of Strategic Information Systems, Vol. 8, pp. 351-71. 
Carter, L. and Belanger, F. (2005), "The utilization of e-government services: citizen trust, innovation and acceptance factors", Information Systems Journal, Vol. 15, pp. 5-25.

Center for Democracy and Technology (CDT) (2002), "E-government handbook for developing countries", CDT Policy Post, Vol. 8 No. 26, pp. 1-10.

Chen, Y. and Gant, J. (2001), "Transforming local e-government services: the use of application service providers", Government Information Quarterly, Vol. 18 No. 4, pp. 343-55.

Choudrie, J. and Lee, H. (2004), "Broadband development in South Korea: institutional and cultural factor", European Journal of Information Systems, Vol. 13 No. 2, pp. 103-14.

Churchill, G. (1987), Marketing Research: Methodological Foundations, Holt, Rinehart \& Winston, New York, NY.

Combe, C. (2009), "Observations on the UK transformational government strategy relative to citizen data sharing and privacy", Transforming Government: People, Process and Policy, Vol. 3 No. 4, pp. 394-405.

Congram, C. and Epelman, M. (1994), "How to describe your service: an invitation to the structured analysis and design technique", International Journal of Service Industry Management, Vol. 6 No. 2, pp. 6-23.

Cooper, R.G. (1979a), "Identifying industrial new product success: project NewProd", Industrial Marketing Management, Vol. 8, pp. 136-44.

Cooper, R.G. (1979b), "The dimensions of industrial new product success and failure", Journal of Marketing, Vol. 43, pp. 93-103.

Cooper, R.G. and de Brentani, U. (1991), "New industrial financial services: what distinguishes winners", Journal of Product Innovation Management, Vol. 8 No. 2, pp. 75-90.

Cooper, R.G. and Kleinschmidt, E.J. (1987a), "New products: what separates winners from losers", Journal of Product Innovation Management, Vol. 4, pp. 169-84.

Cooper, R.G. and Kleinschmidt, E.J. (1987b), "Success factors in product innovation", Industrial Marketing Management, Vol. 16, pp. 215-23.

Cooper, R.G. and Kleinschmidt, E.J. (1987c), "What makes a new product a winner: success factors at the project level”, R\&D Management, Vol. 17, pp. 75-189.

Cooper, R.G., Easingwood, C.J., Edgett, S.J., Kleinschmidt, E.J. and Storey, C. (1994), "What distinguishes the top performing new products in financial services", Journal of Product Innovation Management, Vol. 11 No. 4, pp. 281-99.

Cowell, D.W. (1988), "New service development", Journal of Marketing Management, Vol. 3 No. 3, pp. 313-27.

Daniels, M. (2002), E-government Strategy: Simplified Delivery of Services to Citizens, Office of Management and Budget, Washington, DC.

Davis, F. (1989), "Perceived usefulness, perceived ease of use and user acceptance of information technology”, MIS Quarterly, Vol. 13, pp. 319-40.

de Brentani, U. (1986), “Do firms need a custom-designed new product screening model?”, Journal of Product Innovation Management, Vol. 3, pp. 108-19.

de Brentani, U. (1989), "Success and failure in new industrial services", Journal of Product Innovation Management, Vol. 6, pp. 239-58.

de Brentani, U. (1991), "Success factors in new developing new business services", European Journal of Marketing, Vol. 25 No. 2, pp. 33-59.

de Brentani, U. (1993), "The new product process in financial services: strategy for success", International Journal of Bank Marketing, Vol. 11 No. 3, pp. 15-22.

\section{New service development in \\ e-government}

111 
TG

4,1

112 de Brentani, U. (2001), "Innovative versus incremental new business services: different keys for achieving success", Journal of Product Innovation Management, Vol. 18, pp. 169-87.

de Brentani, U. and Cooper, R.G. (1992), "Developing successful new financial services for businesses”, Industrial Marketing Management, Vol. 21 No. 3, pp. 231-42.

de Brentani, U. and Ragot, E. (1996), "Developing new business-to-business professional services: what factors impact performance", Industrial Marketing Management, Vol. 25 No. 6, pp. 517-30.

Deal, K. and Edgett, S.J. (1997), "Determing success criteria for financial products: a comparative analysis of CART, logit and factor/discriminant analysis", The Service Industries Journal, Vol. 17 No. 3, pp. 489-506.

DeLone, W.H. and McLean, E.R. (1992), "Information systems success: the quest for the dependent variable", Information Systems Research, Vol. 3 No. 1, pp. 60-95.

Dillon, J. and Pelgrin, W. (2002), E-government/Commerce in New York State, Office of Technology, New York, NY.

Doty, P. and Erdelez, S. (2002), "Information micro-practices in Texas rural courts: methods and issues for e-government”, Government Information Quarterly, Vol. 19, pp. 369-87.

Drew, S. (1995), “Accelerating innovation in financial services", Long Range Planning, Vol. 28 No. 4, pp. 11-21.

Dwivedi, Y.K. (2009), "An analysis of e-government research published in transforming government: people, process and policy (TGPPP)", Transforming Government: People, Process and Policy, Vol. 3 No. 1, pp. 7-15.

Earl, M.J. (1994), "The new and old of business process redesign", Journal of Strategic Information Systems, Vol. 3 No. 1, pp. 5-22.

Easingwood, C.J. (1986), "New product development for service companies", Journal of Product Innovation Management, Vol. 3 No. 4, pp. 264-75.

Easingwood, C.J. and Storey, C. (1991), "Success factors for new consumer financial services", International Journal of Bank Marketing, Vol. 9, pp. 3-10.

Edgett, S.J. (1994), "The traits of successful new service development", Journal of Services Marketing, Vol. 8 No. 3, pp. 40-9.

Edgett, S.J. and Parkinson, S. (1994), "The development of new financial services, identifying determinants of success and failure", International Journal of Service Industry Management, Vol. 5 No. 4, pp. 24-8.

Edvardsson, B. (1995), "Tjänsteutveckling med inbyggd kvalitet", Manuscript, Centrum för tjänsteforskning, Högskolan i Karlstad, Karlstad.

Edvardsson, B. (1996a), Kvalitet och tjänsteutveckling, Studentlitteratur, Lund.

Edvardsson, B. (1996b), "Tjänsteutveckling med inbyggd kvalitet”, Forskningsrapport 96:9, Centrum för tjänsteforskning, Högskolan i Karlstad, Karlstad.

E-government Unit (2004), Top of the Web: User Satisfaction and Usage Survey of E-government Services, DG Information Society, European Commission, available at: http://europa.eu.int/information_society/activities/e-government_research/doc/top_of_ the_Web_re-port_2004.pdf

Ekholm, V. and Wrange, K. (1996), “Towards a multilevel service process chart - empirical findings from a pharmaceutical service”, Working Papers No. 322, Swedish School of Economics and Business Administration, Helsinki. 
Elliman, T., Irani, Z., Love, P.E.D., Jones, S. and Themistocleous, M. (2005), "Evaluating e-government: learning from the experiences of two UK local authorities", Information Systems Journal, Vol. 15, pp. 61-82, special issue on e-Government.

Engelbart, D.C. (1962), “Augmenting human intellect: a conceptual framework”, Summary Report AFOSR-3223 under contract AF49 (638)-1024, SRI Project 3578 for Air Force Office of Scientific Research, Stanford Research Institute, Menlo Park, CA.

Ernst, H. (2002), "Success factors of new product development: a review of the empirical literature", International Journal of Management Reviews, Vol. 4 No. 1, pp. 1-40.

Fitzsimmons, J.A. and Fitzsimmons, M.J. (2000), New Service Development: Creating Memorable Experiences, Sage, London.

Fletcher, K. and Wright, G. (1995), "Organizational, strategic and technical barriers to successful implementation of database marketing", International Journal of Information Management, Vol. 15 No. 2, pp. 115-26.

Gefen, D. and Pavlou, P. (2002), "E-government adoption", paper presented at Americas Conference on Information Systems, Tampa, FL.

Gefen, D. and Straub, D. (2000), "The relative importance of perceived ease of use in IS adoption: a study of e-commerce adoption", Journal of the Association for Information Systems, Vol. 1, pp. 1-28.

Gefen, D., Karahanna, E. and Straub, D. (2003), "Trust and TAM in online shopping: an integrated model”, MIS Quarterly, Vol. 27, pp. 51-90.

Gounaris, S.P., Papastathopoulou, P.G. and Avlonitis, G.J. (2003), "Assessing the importance of the development activities for successful new services: does innovativeness matter?", International Journal of Bank Marketing, Vol. 21 No. 5, pp. 266-79.

Grant, G. and Chau, D. (2005), “Developing a generic framework for e-government”, Journal of Global Information Management, Vol. 13 No. 1, pp. 1-30.

Griffin, A. (1997), "PDMA research on new product development practices: updating trends and benchmarking best practices", Journal of Product Innovation Management, Vol. 14 No. 6, pp. 429-58.

Grönroos, C. (1990), Service Management and Marketing: Managing the Moment of Truth in Service Competition, Lexington Books, Lexington, MA.

Gunter, B. (2006), “Advances in e-democracy: overview”, Aslib Proceedings: New Information Perspectives, Vol. 58 No. 5, pp. 361-70.

Hackney, R., Jones, S. and Irani, Z. (2005), "eGovernment information systems evaluation: conceptualising 'customer engagement”, paper presented at eGovernment Workshop '05 (eGOV05), September 13, Brunel University, West London.

Halaris, C., Magoutas, B., Papadomichelaki, X. and Mentzas, G. (2007), "Classification and synthesis of quality approaches in e-government services", Internet Research, Vol. 17 No. 4 , pp. 378-401.

Halchin, L.E. (2004), "Electronic government: government capability and terrorist resource", Government Information Quarterly, Vol. 21, pp. 216-419.

Han, K.S. and Noh, M.H. (2000), "Critical failure factors that discourage the growth of electronic commerce", International Journal of Electronic Commerce, Vol. 4 No. 2, pp. 25-43.

Heeks, R. (2001), "Understanding e-governance for development", Working Papers Series, No. 12/2001, Institute for Development, Policy and Management Information Systems, Technology and Government, University of Manchester, Manchester, available at: http://idpm.man.ac.uk/idpm/igov1labs.htm 
TG

4,1

114

Heeks, R. (2003), "Most e-government-for-development projects fail: how can risks be reduced?", iGovernment Working Paper Series, IDPM, University of Manchester, Manchester.

Ho, A.T.-K. (2002), "Reinventing local governments and the e-government initiative", Public Administration Review, Vol. 62 No. 4, pp. 434-44.

Holden, S.H., Norris, D.F. and Fletcher, P.D. (2003), "Electronic government at the local level: progress to date and future issues", Public Performance \& Management Review, Vol. 26 No. 4, pp. 325-44.

Holland, C.P., Light, B. and Gibson, N. (1999), "A critical success factors model for enterprise resource planning implementation”, in Pries-Heje, J., Ciborra, C., Kantaz, K., Valor, J., Christiaanse, E., Avison, D. and Heje, C. (Eds), Proceedings of the Seventh European Conference on Information Systems, 23-25 June, CBS, Copenhagen, pp. 273-87.

Irani, Z. and Dwivedi, Y.K. (2008), "Editorial", Transforming Government: People, Process and Policy, Vol. 2 No. 4, pp. 221-4.

Irani, Z., Al-Sebie, M. and Elliman, T. (2006), "Transaction stage of e-government systems: identification of its location and importance", Proceedings of the 39th Hawaii International Conference on System Sciences, IEEE, Los Alamitos, CA, pp. 1-9.

Irani, Z., Sahraoui, S., Ozkan, S., Ghoneim, A. and Elliman, T. (2007), "T-government for benefit realisation", Proceedings of the European and Mediterranean Conference on Information Systems, Polytechnic University of Valencia, Valencia, Spain, 24-26 June.

Jaeger, P.T. (2003), "The endless wire: e-government as a global phenomenon", Government Information Quarterly, Vol. 20 No. 4, pp. 323-31.

James, G. (2000), "Empowering bureaucrats", MC Technology Marketing Intelligence, Vol. 20 No. 12 , pp. $62-8$.

Janssen, M. and Shu, W.S. (2008), "Transformational government: basics and key issues", in Janowski, T. and Pardo, T.A. (Eds), Proceedings of the 2nd international Conference on Theory and Practice of Electronic Governance, Cairo, Egypt, 1-4 December 2008, ICEGOV'08, Vol. 351, ACM, New York, NY, pp. 117-22.

Johne, A. and Snelson, P. (1988), "Success factors in product innovation: a selective review of the literature", Journal of Product Innovation Management, Vol. 5 No. 2, pp. 114-28.

Johne, A. and Snelson, P. (1989), "Product development approaches in established firms", Industrial Marketing Management, Vol. 18, pp. 113-24.

Johne, A. and Storey, C. (1998), "New service development: a review of the literature and annotated bibliography", European Journal of Marketing, Vol. 32 Nos 3/4, pp. 184-251.

Joshi, J. and Ghafoor, A. (2001), "Digital government security infrastructure design challenges", IEEE Computer, Vol. 34 No. 1, pp. 66-72.

Kelly, D. and Storey, C. (2000), "New service development: initiation strategy", International Journal of Service Industry Management, Vol. 11 No. 1, pp. 45-62.

Kim, H., Pan, G. and Pan, S. (2007), "Managing IT - enabled transformation in the public sector: case study on e-government in South Korea”, Government Information Quarterly, Vol. 24, pp. 338-52.

Kim, H.W. and Kim, Y.G. (2001), "Rationalizing the customer service process", Business Process Management Journal, Vol. 7 No. 2, pp. 139-56.

Kingman-Brundage, J. (1989), "The ABC's of service system blueprinting”, in Bitner, M.J. and Crosby, L.A. (Eds), Designing a Winning Service Strategy, AMA, Chicago, IL, pp. 30-3.

Kitsios, F. (1996), "Strategic development of the daily regional press", paper presented at the 3rd Conference of Owners of Daily Regional Press Union, Mediterranean Agronomic Institute of Chania, Chania, September. 
Kitsios, F. (2006), "Services marketing in the hospitality economy: an exploratory study", paper presented at 98th EAAE Seminar "Marketing Dynamics within the Global Trading System: New Perspectives", Chania, 29 June-2 July.

Kitsios, F., Doumpos, M., Grigoroudis, E. and Zopounidis, C. (2009), "Evaluation of new services development strategies using multicriteria analysis: predicting the success of innovative hospitality services", Operational Research: An International Journal, Vol. 9 No. 1, pp. 17-33.

Kokko, T. (2005), "Offering development in the restaurant sector - a comparison between customer perceptions and management beliefs", anecdotal $\mathrm{PhD}$ dissertation, Swedish School of Economics and Business Administration, Helsinki.

Lambrinoudakis, C., Gritzalis, S., Dridi, F. and Pernul, G. (2003), "Security requirements for e-government services: a methodological approach for developing a common PKI-based security policy", Computer Communications, Vol. 26 No. 16, pp. 1873-83.

Layne, K. and Lee, J. (2001), "Developing fully functional e-government: a four-stage model", Government Information Quarterly, Vol. 18 No. 2, pp. 122-36.

Lee, S.M., Tan, X. and Trimi, S. (2005), "Current practices of leading e-government countries", Communications of the ACM, Vol. 48 No. 10, pp. 99-104.

Leitner, C. (Ed.) (2003), E-government in Europe: The State of Affairs, European Institute of Public Administration, Maastricht.

Lenk, K. and Traunmüller, R. (2000), "A framework for electronic government”, Database and Expert Systems Applications, Vol. 10, pp. 340-5.

Lievens, A. and Moenaert, R.K. (2000), "Project team communication in financial service innovation”, Journal of Management Studies, Vol. 37 No. 5, pp. 733-66.

McClure, D.L. (2000), "Government online: strategies and challenges”, available at: www.house. gov/reform/gmit/hearings/2000hearings/000522dm.htm (accessed 3 February 2005).

Maidique, M.O. and Zirger, B.J. (1984), "A study of success and failure in product innovation: the case of the US electronics industry", IEEE Transactions on Engineering Management, Vol. 31, pp. 192-203.

Martin, C.R. and Horne, D.A. (1993), "Services innovation: successful versus unsuccessful firms”, International Journal of Service Industry Management, Vol. 4 No. 1, pp. 49-65.

Martin, C.R. and Horne, D.A. (1995), "Level of success inputs for service innovations in the same firm", International Journal of Service Industry Management, Vol. 6 No. 4, pp. 40-56.

Means, G. and Schneider, D. (2000), Meta-capitalism: The E-business Revolution and the Design of 21st Century Companies and Markets, Wiley, New York, NY.

Moon, J. and Kim, Y. (2001), "Extending the TAM for a worldwide-web context", Information \& Management, Vol. 28, pp. 217-30.

Moon, M.J. (2002), "The evolution of e-government among municipalities: rhetoric or reality", Public Administration Review, Vol. 62 No. 4, pp. 424-33.

Moon, M.J. and Norris, D.F. (2005), "Does managerial orientation matter? The adoption of reinventing government and e-government at the municipal level", Information Systems Journal, Vol. 15, pp. 43-60.

Murphy, J. (2005), "Beyond e-government the world's most successful technology-enabled transformations", Executive Summary, INSEAD: the Business School for the World, Fontainbleau, pp. 1-124, available at: www.localtgov.org.uk

Myers, S. and Marquis, D. (1969), Successful Industrial Innovations, National Science Foundation, Washington, DC, pp. 69-71. 
TG

4,1

National Research Council (2002), Information Technology Research, Innovation, and E-government, National Academy Press, Washington, DC.

Nedovic-Budic, Z. and Godschalk, D.R. (1996), "Human factors in adoption of geographic information systems: a local government case study", Public Administration Review, Vol. 56 No. 6, pp. 554-67.

Norling, P. (1993), Tjänstekonstruktion, CTF, University of Stockholm, Stockholm.

Norris, D.F. and Campillo, D. (2000), Factors Affecting Innovation Adoption by City Governments: The Case of Leading Edge Information Technologies, Maryland Institute for Policy Analysis and Research, University of Maryland, Baltimore, MD.

Norris, D.F. and Demeter, L.A. (1999), "Computing in American city governments", The 1999 Municipal Yearbook, International City/County Management Association, Washington, DC, pp. 10-19.

Northrop, A., Debora Dunkle, D., Kraemer, K. and King, J. (1994), “Computers, police and the fight against crime: an ecology of technology, training and use", Information and the Public Sector, Vol. 3, pp. 21-45.

OECD (2000a), Annual Report 2000, Organisation for Economic Cooperation and Development, available at: www.oecd.org/dataoecd/30/59/1842666.pdf (accessed 3 February 2005).

OECD (2000b), "Science, technology and industry", The Service Economy Business and Industry Policy Forum Series, Organisation for Economic Cooperation and Development, Paris.

Ottenbacher, M. and Gnoth, J. (2005), "How to develop successful hospitality innovation", Cornell Hotel \& Restaurant Administration Quarterly, Vol. 46 No. 2, pp. 205-22.

Ottenbacher, M., Gnoth, J. and Jones, P. (2006), "Identifying determinants of success in development of new high-contact services", International Journal of Service Industry Management, Vol. 17 No. 4, pp. 344-63.

Pagani, M. and Pasinetti, C. (2009), Accessibility, Usability, and Functionality in T-government Services, IGI Global, Hershey, PA.

Palanisamy, R. (2004), "Issues and challenges in e-governance planning”, Electronic Government, Vol. 1 No. 3, pp. 253-73.

Papadomichelaki, X., Magoutas, B., Halaris, C., Apostolou, D. and Mentzas, G. (2006), Designing Government Services, A Review of Quality Dimensions in E-government Services, Lecture Notes in Computer Science, Springer, Berlin.

Parkinson, S. (1981), "Successful new product development - an international comparative study", $R$ \& D Management, Vol. 11 No. 2, pp. 79-85.

Rogers, E. (1995), Diffusion of Innovations, 4th ed., The Free Press, New York, NY.

Sarikas, O.D. and Weerakkody, V. (2007), "Realising integrated e-government services: a UK local government perspective”, Transforming Government: People, Process and Policy, Vol. 1 No. 2, pp. 153-73.

Scheuing, E.E. and Johnson, E.M. (1989), “A proposed model for new service development”, Journal of Services Marketing, Vol. 3 No. 2, pp. 25-34.

Scholl, H. (2002), "Current practices in e-government induced business process change (BPC): an empirical study of current practices", International Journal of Electronic Government, Vol. 1 No. 2, pp. 27-49.

Shah, M.H. and Siddiqui, F.A. (2006), "Organisational critical success factors in adoption of e-banking at the Woolwich bank", International Journal of Information Management, Vol. 26 No. 2, pp. 442-56. 
Shostack, G.L. (1981), "How to design a service”, European Journal of Marketing, Vol. 16 No. 1, pp. 49-63.

Shostack, G.L. (1984), "Designing services that deliver", Harvard Business Review, January-February, pp. 133-9.

Shostack, G.L (1985), "Planning the service encounter", in Czepiel, J.A., Solomon, M.R. and Surprenant, C.F. (Eds), The Service Encounter, Lexington Books, Lexington, MA.

Simon, H.A. (1976), Administrative Behavior, 3rd ed., The Free Press, New York, NY.

Smith, D. (2007), "From e to t: the implications of transformational government for library services", Journal for Library and Information Specialists, Spring, pp. 8-12.

Storey, C. and Easingwood, C. (1993), "The impact of the new product development project on the success of financial services”, The Services Industry Journal, Vol. 13 No. 3, pp. 40-54.

Storey, C. and Easingwood, C. (1996), "Determinants of new product performance: a study in the financial services sector", International Journal of Service Industry Management, Vol. 7 No. 1, pp. 32-55.

Tax, S.S. and Stuart, I. (1997), "Designing and implementing new services", Journal of Retailing, Vol. 73 No. 1, pp. 105-34.

Themistocleous, M. and Irani, Z. (2002), "Evaluating enterprise application integration technologies: a novel frame of references", European Journal of Operational Research, Vol. 159 No. 2, pp. 393-405.

United Nations and American Society for Public Administration (ASPA) (2002), Benchmarking E-government: A Global Perspective, UN Publications, New York, NY.

van Riel, A.C.R., Lemmink, J. and Ouwersloot, H. (2004), "High-technology service innovation success: a decision-making perspective", Journal of Product Innovation Management, Vol. 21 No. 5, pp. 348-59.

Venkatesh, V. and Davis, F. (2000), "A theoretical extension of the technology acceptance model: four longitudinal field studies”, Management Science, Vol. 46, pp. 186-204.

Venkatesh, V. and Morris, M. (2000), "Why don't men ever stop to ask for directions? Gender, social influence, and their role in technology acceptance and usage behaviour", MIS Quarterly, Vol. 24, pp. 115-39.

Weerakkody, V. and Dhillon, G. (2008), "Moving from e-government to t-government: a study of process reengineering challenges in a UK local authority context", International Journal of Electronic Government Research, Vol. 4 No. 4, pp. 1-16.

Weerakkody, V., Janssen, M. and Hjort-Madsen, K. (2007), "Realising integrated e-government services: a European perspective", Journal of Cases in Electronic Commerce, Vol. 3 No. 2, pp. 14-38.

West, D. (2004), "E-government and the transformation of service delivery and citizen attitudes", Public Administration Review, Vol. 64 No. 1, pp. 15-27.

Wilhelmsson, M. and Edvardsson, B. (1994), "Utveckling av nya Tjänster - Referensram och fallstudier”, Forskningsrapport 94:18 (Samhällsvetenskap), Centrum för tjänsteforskning, Högskolan i Karlstad, Karlstad.

World Bank (2003), “Task managers' ICT toolkit: good practice for planning, delivering and sustaining ICT products", Report No. 25919-A/B, Global ICT Department, Washington, DC.

World Bank (2004), "E-government: a definition of e-government", available at: http://go.worldbank.org/M1JHE0Z280 (accessed 3 February 2005). 
TG

4,1

118

Wrange, K. (1997), "Relationship termination intentions - a study of hotel customers", unpublished Licentiate thesis manuscript, Center for Relationship Marketing and Service Management, Swedish School of Economics and Business Administration, Helsinki.

Yildiz, M. (2007), "E-government research: reviewing the literature, limitations, and ways forward", Government Information Quarterly, Vol. 24, pp. 646-65.

Zeithaml, V.I. and Bitner, M.J. (1996), Services Marketing, McGraw-Hill, New York, NY.

Zopounidis, C. and Doumpos, M. (2002), "Multicriteria classification and sorting methods: a literature review", European Journal of Operational Research, Vol. 138 No. 2, pp. 229-46.

\section{Further reading}

Churchill, G. and Peter, P. (1984), "Research design effects on the reliability of rating scales: a meta-analysis", Journal of Marketing Research, Vol. 21 No. 4, pp. 360-75.

Cooper, R.G. (1998a), "Benchmarking new product performance: results of the best practices study", European Management Journal, Vol. 16 No. 1, pp. 1-17.

Cooper, R.G. (1998b), Product Leadership: Creating and Launching Superior New Products, Perseus Books, New York, NY.

Cooper, R.G. and Kleinschmidt, E.J. (1990), New Products: The Key Factors in Success, American Marketing Association, Chicago, IL.

Cooper, R.G. and Kleinschmidt, E.J. (1991), "New product process at leading industrial firms", Industrial Marketing Management, Vol. 10 No. 2, pp. 137-47.

Cooper, R.G. and Kleinschmidt, E.J. (1993), "Uncovering the keys to new product success", Engineering Management Review, Vol. 11, pp. 5-18.

de Brentani, U. (1999), "An empirical analysis of the effect of product innovativeness on success and failure of new industrial services", Conference Proceedings ANZMAC 1999, University of New South Wales, Sydney.

Johne, A. and Snelson, P. (1988), "Marketing's role in successful product development”, Journal of Marketing Management, Vol. 3 No. 3, pp. 256-68.

Johne, A. and Snelson, P. (1990), Successful Product Development: Lessons from American and British Firms, Blackwell, Oxford.

Johnson, C. (2002), "Locational strategies of international hotel corporations in Eastern central Europe", anecdotal Phd, Faculty of Economic and Social Sciences, University of Fribourg, Fribourg.

Weerakkody, V., Dwivedi, Y.K., Dhillon, G. and Williams, M.D. (2009), "Realising t-government: a UK local authority perspective", Computer Society of India, available at: www.csi-sigegov.org/1/35_340.pdf

\section{Corresponding author}

Spyros Angelopoulos can be contacted at: spyros.angelopoulos.09@mail.wbs.ac.uk

To purchase reprints of this article please e-mail: reprints@emeraldinsight.com Or visit our web site for further details: www.emeraldinsight.com/reprints 